\title{
Actions Related to Care and Management of Nursing Work Process in Primary Health Care

\author{
Marcelo Costa Fernandes ${ }^{1}$, Lucilane Maria Sales da Silva ${ }^{2}$, \\ Thereza Maria Magalhães Moreira², Maria Rocineide Ferreira da Silva ${ }^{2}$
}

\section{Abstract}

Introduction: This study aimed to analyze the nursing work process in Primary Health Care with emphasis on care and management actions.

Method: Qualitative research with 32 nurses from Maracanaú municipality in the state of Ceará. Data collection was performed in 2012 through semi-structured interview.

Results: It was observed that the main care actions are related to programs of the Ministry of Health and active search. In turn, management actions are activities of supervision and construction of the service schedule.

Conclusion: In conclusion, nursing work process in this level of care was proved to be still strongly influenced by the traditional model of health care, with practices that reflect the hegemony of biomedical knowledge.

\section{Introduction}

The nursing work process is characterized by complex and diverse actions, carried out individually and collectively, seeking the promotion, protection and recovery of health, as well as converging with the doctrinal and organizational principles of the Unified Health System (UHS).

Among the various facilities where nursing work is carried out, the Family Health Strategy (FSH) stands out. This was instituted by the National Policy of Primary Care (NPPC) as a key strategy for the reorganization, expansion and consolidation of assistance in Primary Care (PC) [1].
1 Federal University of Campina Grande, Cajazeiras, PB, Brazil.

2 Ceará State University, Fortaleza, CE, Brazil.

Contact information:

\section{Marcelo Costa Fernandes.}

Address: Federal University of Campina Grande. Rua Sérgio Moreira de Figueiredo, Bairro Casas Populares, Cajazeiras, PB. CEP: 58900-000.

Đcelo_cf@hotmail.com

\section{Keywords}

Public Health Nursing;

Nursing care; Management;

Administration of Patient Care. 
Actions developed in PC aim to develop a comprehensive care that impact on health status and autonomy of individuals and on determinants and health conditioners of communities while viewing the individual in its uniqueness and social and cultural insertion [2].

In this environment of care, nursing may have a role in different practical dimensions such as care, manage, educate, research and may have a role in political issues. These are not isolated, but often related and concomitant [3].

However, the present research will address the dimensions of care and manage because these are the most obvious actions in the everyday nursing practice and also because they reflect influences of the historical process that permeates the consolidation of this professional category, marked with the presence of fragmented, technical and reductionist activities.

This investigation will contribute and allow nursing to gain greater clarity of its work process and it will encourage the realization of more flexible, ethical, integral, constructive and democratic relations within the $\mathrm{PC}$.

Thus, this study aims to analyze the nursing work process in Primary Care with emphasis on care and management actions.

\section{Method}

This is a descriptive study with a qualitative approach carried out with 32 nurses from the FHS of Maracanaú-CE. As criteria for inclusion, only nurses who had been working for more than twelve months at the facility were invited to participate. This period is considered the minimum needed for a nurse to become familiarized with the dynamics of the FHS. As criteria for exclusion, nurses who were on vacation, on sick leave or away did not participate.

We used a semi-structured interview as data collection technique. Interviews took place in the period between May and July 2012 in a private room of the basic health unit. Suspension of data collection occurred at the moment when theoretical saturation was identified.

The methodological process known as Collective Subject Discourse (CSD), which is a tool that enables the representation of thought of a particular group, was adopted to proceed with ordination and organization of empirical data produced by the semistructured interviews with selected nurses in this investigation. This methodology proposes the sum of ideas not in a numerical manner, but operationalizing in a methodological manner the expression of the collective thought through discourse [4].

The CSD's proposal is basically to analyze the material built by a community through testimonials and then extract the Central Ideas $(\mathrm{Cl})$ and their key-expressions (KEX). At the end, the content of responses with similar meaning is gathered in discoursessynthesis written in the first singular person [4].

The KEX can be defined as fragments, excerpts or verbatim transcripts of discourse that must be highlighted by the researcher and that reveal the essence of the whole of observed discourse. In turn, $\mathrm{Cl}$ is a name or linguistic expression that reveals and describes, the meaning of each discourse analyzed and of each homogenous set of KEX the most concise and precise as possible, which will give rise later to the CSD [4].

Regarding the analysis of interviews content, initially, there was a brief reading of the lines in order to understand all the transcripts. Subsequently, successive readings were necessary to make it possible to identify the units of meaning related to guiding questions that composed the interview script. Then, KEX of each response were identified, represented by literal words of nurses. These expressions built up the $\mathrm{Cl}$ which were organized and will be presented in four categories with respective CSD.

The research started after approval by the Ethics Committee of the State University of Ceará-UECE under opinion $\mathrm{N}^{\circ}$ 26907. Ethical and legal components are present at all stages of the research, in accordance with Resolution 466/12 of the National Health Council. 
Aims, methods, anticipated benefits or potential risks of the research were made clear. Participants of the study were asked to sign the Informed Consent, informing the guaranteed anonymity and freedom to participate or withdraw consent at any stage of the research.

\section{Results}

It was possible to identify four discourses based on the speeches of nurses regarding the work process in the dimensions of care and management. These will be presented and discussed with their respective CSD.

The first discourse focuses on care actions based on programs of the Ministry of Health and six nurses participated in the construction of the CSD:

\section{Care actions perceived from programs of the Ministry of Health}

Actually, in relation to care actions that we perform in the family health strategy, they are all actions following programs of the Ministry of Health. Nursing care is organized and directed to the various programs. My schedule is organized this way: Monday morning and afternoon I take care of prenatal; Tuesday morning I perform gynecological prevention and in the afternoon, home visits; Wednesday morning childcare, and afternoon, family planning; Thursday morning and afternoon I assist patients with hypertension and diabetes and on Friday morning I usually do meetings with the Community Health Agents (CHA). All these services are part of my weekly schedule and this follows the programs of the Ministry of Health.

CSD 01.

The CSD 02 addresses the active search that nurses perform toward users in Primary Care. Four nurses participated in building the CSD which gave rise to the following discourse:

\section{Active search as a care action toward users of} Primary Care

We constantly conduct active search for users here in the community. Active search occurs when I leave the health unit and go to the community after a user. I do active search after persons with respiratory symptoms, as in the case of tuberculosis, and active search after persons with dermatological symptoms, for leprosy. I do active search until I make that missing person to come back and give continuity to our monitoring.

CSD 02

The CSD 03 addresses supervisory managerial actions. Eight interviews of nurses were used for the construction of the following CSD:

\section{Supervision activities of the health facility}

Here at the health unit, the nurse is in charge of the supervision of some services some professionals. For the services, I supervise, along with other nurses of the unit, the vaccination room, ambulatory, nebulization room, prevention room and sterilization room. The nurse is also responsible for overseeing the nursing technician and the nursing assistant, as well as for CHA. It also supervises CHA in our area. I always do a talk and transmit some new information.

CSD 03.

The last discourse addresses the construction of the service schedule. Six interviews of nurses were used for construction of the CSD shown below:

\section{Construction of service schedule}

One management activity that we develop is to build our service schedule. So, there is this planning, this organization of nursing care schedule, and depending on the audience we always have to make adjustments. The planning of my schedule has to be well done, properly planned so that I can serve well the people of this area

CSD 04 


\section{Discussions}

It is evident in the CSD 01 that nursing care activities in $\mathrm{PC}$ remain limited to the schedule of the Ministry of Health and especially, under the logic of individual clinical care, of curative nature and without expanding the understanding of the health/disease process as a social production once care actions cited are directed to specific groups, with emphasis on diseases, procedures and medical treatment.

However, care activities that the nurse performs in this level of care could be carried out independently of the program of Ministry of Health, given that the professional legislation of the nurse contemplates care actions that can be implemented in PC, activities such as nursing consultation, prescription assistance, preparation, execution and evaluation of health-care plans and educational activities aimed at improving the health of the population [5].

Similar statements with limited practices were found in a study with nurses from the basic health network of Ribeirão Preto. In this study, examination of gynecological prevention, home visits, childcare visits, prenatal, family planning and care for hypertensive and diabetic users were also identified as major activities of these professionals in PC. So, the nurse conducts limited care actions in care protocols [6-7].

In this context of practices, nursing care has been unable to facilitate actions for the real health needs of users. There is therefore an emphasis on technical procedures, as noted in the CSD 01, through compliance of rules and standards and prioritization of tasks turned to biological aspects of human beings. This often makes the nursing care a fragmented and mechanical activity, focused on procedures, and with an offer of assistance based on the disease [8-9].

Also noteworthy is that it was not possible to perceive in the CSD 01 the presence of use of soft technologies by nurses in their care, such as listening, welcoming, accountability and independence, which shows that the practice at that level of care is still strongly influenced by the biomedical model, hegemonic and focused on procedures.

When it comes to PC, nursing could have a work process that expresses the theoretical, methodological and scientific knowledge inherent to the area, one that, even guided by the ministerial program, can translate thought and legislative and traditional practice to the one that demonstrates thinking and policies of training these professionals.

The practice of active search, despite being referred to by nurses in the CSD 02 as a caring action, it is understood as having a stronger managerial connotation, given that this action requires organization, planning, coordination. In the manner as it is mentioned, it seems to be only a mechanism to ensure the return of defaulting users to give continuity to care actions, which, according to the speeches should take place in the health unit areas. However, according to the guidelines that guide health actions of the PC, nursing care can take place in the own territory, that is, at home, community and other social spaces.

With respect to the performance of active search by nurses, the CSD 02 converges with the rules and guidelines of the ordonnance of PC, since this activity is an assignment common to all professionals, including nurses, and it is one of the expectations of the practice of such workers in the territory [10].

Active search is understood as a move against the automation of spontaneous demand, to map the health needs of users in addition to the mandatory reporting of diseases of a particular territory, as well as to maintain and strengthen the bond with both the user and with his/her family. This action also allows to know the experienced reality and preserve the integrity of life [11-12].

If active search is understood as a technical procedure of symptomatic identification, a geometric understanding of the territory is assumed, and this is seen in the CSD 02 of nurses. However, understanding the active search as a political principle of territorial logic of care supposes a relationship 
with a territory that is not something static, but an environment full of movement of forces, a tissue in which subjectivity is produced and in which life expands or is constrained in its movement. It would be an opportunity for the exercise of care in addition to the health unit structure, like a nursing consultation with listening and reception held at home [11].

Thus, when the nurse leaves the health unit and approach the community, he/she will be able to build a care that will meet the real health needs of users, family and community, which is made possible also by doing active search.

According to Law $N^{\circ} 7,498$ of June 25, 1986, it is the nurse's prerogative planning, organization, coordination, execution and evaluation of nursing care services. This set of actions is inserted in carrying out supervisory activities. Therefore, supervision is a management activity inherent to the nurse and this can exercise it with legal support, as shown in the CSD 03 [5].

Nevertheless, according to nurses of this study, supervisory activities are not restricted to the service and the nursing staff in the PC work process, but the whole structure and dynamics of operation of the health facility, covering several areas, including materials, people and organizational resources.

Supervision is an activity inherent to the nurse's daily life in PC, as this activity presents the educational (both in the educational aspect of other workers as the training of character) and control (activities and staff) dimensions and can still have the purpose of checking, correcting and reporting [7].

According to the CSD 03 of nurses, there is democratization of activities at this level of care. The supervisory actions in sectors of health facilities such as the vaccination room, ambulatory, nebulization room, prevention room and sterilization room, are shared between nurses. This favors reduction of overloading functions and consequently better planning of these services, once the management of the necessary inputs for the proper functioning of these sectors will be carried out with greater efficiency and effectiveness.

Another point present in the CSD 03 is the supervision that the nurse performs with the Community Health Agents (CHA), nursing assistants and technicians. This supervision that the nurse develops beyond the evaluator and disciplinarian aspect, as noted in the discourse, also has educational character.

Finally, construction of service schedule in PC relates is listed as a management activity according to CSD 04 nurses. Therefore, this action developed for the organization of service aims at making decisions that affect the structure, the production process and the product of the system involving the nurse's work at this level of care.

The mentioned planning and organization of schedule are in accordance with the rules and guidelines of the national policy of Primary Care, because according to this ordinance programming and implementation of health care actions based on real health needs of the population are activities pertinent not only to nurses but also to the other members of the team [10].

Advances in nursing management practice can also be perceived by the CSD 04 in the sense that the reality of women workers who live and work in the community was taken into account when drawing up the schedule, which provided conditions for them from attending the institution. This proves that when the service and professionals are aware of the reality of the territory, health actions can be better offered to the population.

Therefore, management actions developed with more flexibility can be a potential tool for carrying out activities not in compliance with fragmented tasks centered on the development of isolated procedures, but practices directed to the real demands of the service and the territory attached to the service unit. 


\section{Conclusion}

The trajectory in this study examined the nursing work process in Primary Care with emphasis on the care and management actions. Actions as planned by the Ministry of Health and active search stand out as the main care activities. In turn, the most obvious managerial actions based on the discourse of nurses were the supervision and construction of the service schedule.

Nursing work process in this level of care is understood as still strongly influenced by the traditional model of health care, with practices that reflect the dominance of biomedical knowledge, restricted to biological process, prescriptive and loyal to the positivist understanding of science.

The present research has limitations with regard to the research in Primary Care of a single municipality, so that the work process that nursing performs in this scenario depends on the territory dynamics, professionals and users who live in this environment. Thus results cannot be generalized to the rest of services in the country.

As a contribution of this study, it is expected to sensitize nurses inserted in teaching, research and practice of the importance of adding actions that may value the uniqueness and the multidimensionality of social actors who seek health services to the current working arrangements, as well as greater integration, flexibility, communication between members of the healthcare team in order to make the plan consistent with local realities.

\section{References}

1. Fernandes MC, Silva LMS. Nurse care management in the family health strategy: integrative review Rev Rene [Internet]. 2013 [cited 2014 Sep 25]; 14(2): 438-47. Available from: www. revistarene.ufc.br/revista/index.php/revista/article/view/42/ pdf 1

2. Ministério da Saúde (BR). Portaria GM nº. 2488, de 21 de outubro de 2011. Aprova a Política Nacional de Atenção Básica, estabelecendo a revisão de diretrizes e normas para a organização da Atenção Básica, para a Estratégia Saúde da Família (ESF) e o Programa de Agentes Comunitários de Saúde (PACS). Diário Oficial da União 2011; 24 out.

3. Sanna MC. Os processos de trabalho em Enfermagem. Rev. bras. enferm. [Internet]. 2007 [cited 2014 Sep 26]; 60(2): 221224. Available from: http://www.scielo.br/scielo.php?script=sci arttext\&pid=S0034-71672007000200018\&lng=en

4. Lefèvre F, Lefèvre AMC. O discurso do sujeito coletivo: um novo enfoque em pesquisa qualitativa (desdobramentos). 2.ed. Caxias do Sul (RS): Educs; 2005.

5. Brasil. Lei 7.498, de 25 de junho de 1986. Dispõe sobre a Regulamentação do Exercício da Enfermagem e dá outras providências. Brasília: Ministério da Saúde; 1986. [citado em 25 set 2014]. Disponível em: http://www2.camara.gov.br/internet/ legislacao/legin.htm

6. Matumoto S, Fortuna CM, Kawata LS, Mishima SM, Pereira MJB. Nurses' clinical practice in primary care: a process under construction. Rev. Latino-Am. Enfermagem [Internet]. 2011 [cited 2014 Sep 25] ; 19(1): 123-130. Available from: http://www.scielo.br/scielo.php?script=sci arttext\&pid=S0104$\underline{11692011000100017 \& \text { Ing }=e n}$

7. Kawata LS, Mishima SM, Chirelli MQ, Pereira MJB, Matumoto S, Fortuna CM. Attributes mobilized by nurses in family health: reaching performances when developing managerial competence. Rev. esc. enferm. USP [Internet]. 2011 [cited 2014 Sep 25] ; 45 (2): 349-355. Available from: http://www.scielo.br/scielo.php?script=sci_arttext\&pid=S0080$\underline{62342011000200007 \& \operatorname{lng}=\mathrm{en}}$

8. Assis WD, Collet N, Reichert APS, Sá LD. Processo de trabalho da enfermeira que atua em puericultura nas unidades de saúde da família. Rev. bras. enferm. [Internet]. 2011 [cited 2014 Sep 25] ; 64(1): 38-46. Available from: http://www.scielo.br/scielo.php?script=sci_arttext\&pid=S003471672011000100006\&lng=en

9. Souza ACC, Muniz FMJM, Silva LF, Monteiro ARM, Fialho AVM. Formação do enfermeiro para o cuidado: reflexões da prática profissional. Rev. bras. enferm. [Internet]. 2006 [cited 2014 Sep 25] ; 59(6): 805-807. Available from: http://www.scielo.br/scielo.php?script=sci arttext\&pid=S003471672006000600016\&lng=en 
10. Ministério da Saúde (BR). Portaria GM n. 2488, de 21 de outubro de 2011. Aprova a Política Nacional de Atenção Básica, estabelecendo a revisão de diretrizes e normas para a organização da Atenção Básica, para a Estratégia Saúde da Família (ESF) e o Programa de Agentes Comunitários de Saúde (PACS). Diário Oficial da União 2011; 24 out.

11. Lemke RA, Silva RAN. A busca ativa como princípio político das práticas de cuidado no território. Estud Pesqui Psicol. [Internet]. 2010 [cited 2014 Sep 25]; 10(1):281-95. Available from: http:// pepsic.bvsalud.org/scielo.php?script=sci arttext\&pid=\$180842812010000100018\&lng=pt\&tlng=pt

12. Heck RM, Kantorski LP, Borges AM, Lopes CV, Santos MC, Pinho $L B$. The interventions of professionals of a psychosocial care center towards clients who attempted or are at a risk of suicide. Texto contexto - enferm. [Internet]. 2012 [cited 2014 Sep 25]; 21(1): 26 33. Available from: http://www.scielo.br/scielo.php?script=sci arttext\&pid=S0104-07072012000100003\&lng=en
Comment on this article:

\section{(f) B in $8+\mathbf{S}$}
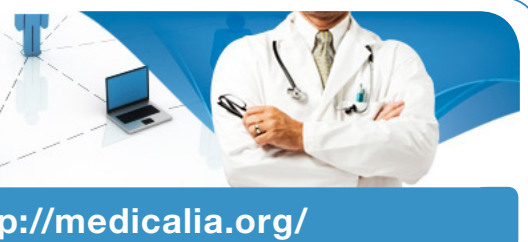

http://medicalia.org/

Where Doctors exchange clinical experiences, review their cases and share clinical knowledge. You can also access lots of medical publications for free. Join Now!

\section{Publish with iMedPub}

http://www.imed.pub

International Archives of Medicine is an open access journal publishing articles encompassing all aspects of medical science and clinical practice. IAM is considered a megajournal with independent sections on all areas of medicine. IAM is a really international journal with authors and board members from all around the world. The journal is widely indexed and classified Q1 in category Medicine. 